\title{
The Potential of Magnesium Based Materials in Mandibular Reconstruction
}

\author{
Somasundaram Prasadh ${ }^{1}{ }^{(0)}$, Vaishnavi Ratheesh $\left.{ }^{1} \mathbb{(}\right)$, Vyasaraj Manakari ${ }^{2}{ }^{\mathbb{D}}$, Gururaj Parande ${ }^{2} \mathbb{D}$, \\ Manoj Gupta $2, * \mathbb{1}$ and Raymond Wong $1, *$ (D) \\ 1 Faculty of Dentistry, National University of Singapore, 11 Lower Kent Ridge Road, Singapore 119083, \\ Singapore; e0204949@u.nus.edu (S.P.); vaishuratz@gmail.com (V.R.) \\ 2 Department of Mechanical Engineering, National University of Singapore, 9 Engineering Drive 1, \\ Singapore 117576, Singapore; mbvyasaraj@u.nus.edu (V.M.); gururaj.parande@u.nus.edu (G.P.) \\ * Correspondence: mpegm@nus.edu.sg (M.G.); denrwcw@nus.edu.sg (R.W.); \\ Tel.: +65-6516-6358 (M.G.); +65-9786-6546 (R.W.)
}

Received: 14 February 2019; Accepted: 2 March 2019; Published: 7 March 2019

\begin{abstract}
The future of biomaterial design will rely on development of bioresorbable implant materials that completely and safely degrade in vivo after the tissues grow, without generating harmful degradation products at the targeted anatomic site. Permanent biomaterials such as Ti6Al4V alloy, 316L stainless steel, and Co-based alloys currently used in mandibular reconstruction often result in stress shielding effects due to mismatch in the Young's modulus values between the bone and the implant, resulting in implant loosening. Also, allergic responses due to metal ion releases necessitates revision surgery to prevent long term exposure of the body to toxic implant contents. Bioresorbable metals are perceived as revolutionary biomaterials that have transformed the nature of metallic biomaterials from bioinert to bioactive and multi-bio functional (anti-bacterial, anti-proliferation, and anti-cancer). In this aspect, magnesium (Mg)-based materials have recently been explored by the biomedical community as potential materials for mandibular reconstruction, as they exhibit favorable mechanical properties, adequate biocompatibility, and degradability. This article reviews the recent progress that has led to advances in developing Mg-based materials for mandibular reconstruction; correlating with the biomechanics of mandible and types of mandibular defects. Mg-based materials are discussed regarding their mechanical properties, corrosion characteristics, and in vivo performance. Finally, the paper summarizes findings from this review, together with a proposed scope for advancing the knowledge in Mg-based materials for mandibular reconstruction.
\end{abstract}

Keywords: magnesium; biomaterials; biodegradation; endoprosthesis; mandibular reconstruction

\section{Introduction}

The mandible is the largest and the strongest bone in the human face, serving as a support to the oral musculature and thereby aiding in articulation, respiration, deglutition, and mastication. Furthermore, it is crucial in maintaining the facial profile by supporting the skeletal base for teeth [1]. Several issues like tumor resection, congenital defects, and associated trauma needing many reconstructive surgeries in the mandibular zone is one of the routine challenges in clinical practice [2]. One of the potential challenges often encountered by clinicians is the oromandibular reconstruction during episodes of benign/malignant tumor resection, and management of osteomyelitis or the osteoradionecrotic mandible. Mandibular defects often occur due to the surgical therapies for malignant tumors surfacing in the neck and head regions. Often, these defects jeopardize both form and function of the mandible, requiring a multi-disciplinary approach to restore their function 
and aesthetics. Significant factors to be considered during the reconstruction of such defects include the re-establishment of facial dimensions in terms of their width, height, and projection. Despite the advancements, during the critical assessment of the reconstructed oral cavity, functional deficits are often encountered. Besides radical removal of the tumor, current prospects of maxillofacial surgery demand subsequent primary/secondary reconstruction taking into consideration the patient factors that have an important role in terms of efficient function, aesthetics, and dental rehabilitation. Various surgical methodologies have been adopted for mandibular defect reconstruction that possess unique advantages and limitations. Some of these surgical procedures include free bone graft, reconstruction plate, particulate bone cancellous marrow graft, transport distraction osteogenesis, microvascular free flap, pedicle bone graft, modular endoprosthesis, and tissue engineering.

The current gold standard treatment modalities for mandibular defect reconstruction includes: (a) vascularized microvascular free fibula flap or (b) an autogenous free bone graft. However, the bone graft treatment possesses certain limitations, such as its inability to replicate the complex geometry of the original mandible. Further, it also lacks in mimicking the aesthetic and function aspect completely like the original. Time-consumption, hospitalization, and associated significant donor-site morbidity are several limitations of these methods. In recent times, cascading research work strives at addressing the shortcomings encountered and attempts to investigate alternative procedures for mandibular reconstruction from a clinical point of view. Lee et al. [3] introduced a unique way for mandibular reconstruction using modular endoprosthesis using titanium alloy. The remaining bone stumps on either side of the mandibular defect were cemented using prosthetic stems. Six months post-surgery, the results revealed increased bone formation around the body of the modular endoprosthesis. However, this approach exhibited few limitations, wherein the soft-tissue healing was not ideal, leading to dehiscence and concentrated hardware exposure in some cases. Additionally, a hardware failure in the form of endoprosthesis screws loosening was also encountered [3-5]. Tissue engineering is a great alternative to alleviate these limitations and to aid in the regeneration of original geometry without the presence of donor-site morbidity. Hence, tissue engineering could be a superior alternative for mandibular reconstruction.

Current implant research has a special focus on biodegradable magnesium (Mg)-based alloys. Regarding the regeneration of hard and soft musculoskeletal tissues, the current literature seems to be promising for Mg-alloys [6-34], as they could serve as valuable resources for customized engineering of degradable craniofacial implants. Procedures such as bone graft stabilization during reconstructions, osteotomies, and trauma reconstruction are often performed with the utilization of craniofacial implants like plates and screws [35]. Metals such as 316L stainless steel, Co-Cr, Ti6Al4V, vitallium, and other metal alloys have been previously used for the development of craniofacial bone plates and screws [35]. Among all these metals, titanium possessing an excellent osseointegrative property with the mammalian bone potentiating it as the permanent metal of choice for reconstructive surgeries [36]. Even though titanium is routinely used, literature records $10-12 \%$ of cases in which the craniofacial implants had to be removed for various reasons such as discomfort, infection, pain, and exposure [36]. Other biomaterials that are gaining popularity are the resorbable polymer plates and screws that can be used in craniofacial implants, as they promote stabilization and fixation, but their stability is only temporary [36]. Nevertheless, the biomechanical properties of biodegradable polymers such as polycaprolactone and poly-l-lactide are far less superior compared to their metal counterpart [37]. Requisites such as a heating device to make the implant malleable and the need to tap the bone prior to screw placement are other disadvantages encountered [38]. Factors such as strength and ability to degrade allows the degradable metals to possess greater superiority than the polymer and permanent metal counterparts. $\mathrm{Mg}$ is one such degradable metal that has been researched in the recent past [39-42]. Previous in-vitro studies evaluated the efficacy of $\mathrm{Mg}$ alloy screws [39-42]. Magnesium alloy cylinders and rods have been implanted into guinea pig femurs [25,26], rat femurs [30,33], rabbit femurs [13,16,20-23,27-29,31,32,34], and tibias $[6,8-12,14,15,17-19]$, as well as sheep hip bones [7,24]. Data on inflammatory and immune 
responses demonstrated that degrading $\mathrm{Mg}$ scaffolds showed acceptable biocompatibility and seemed to react in-vivo with an amount of considerable inflammatory host response $[6,9,16,23,28-30,33,34]$. Researchers have also observed that bone formation [7-11,13,17-21,24-27,30-34] was followed by the subsequent osteoblastic activity [16,24,25,27,30,33]. Considering the studies that involved varied types of magnesium alloys, major work was carried out with AZ31 alloy which is commercially available and earlier experimented in-vivo in the form of screws [7,24] and rods [25,32]. Results depicted the considerable amount of bone being deposited surrounding the AZ31 implants $[7,24,25,32]$. According to Willbold et al., the location of the AZ31 in the original tissue determined their corrosion behavior [24]. Subsequently, bone formation was appreciated all around the magnesium rods [25] and minimal changes in the composition of blood were observed with no signs of inflammation from the degrading implant [32].

In order to optimize the type of bone scaffolds based on the principles of tissue engineering, bone grafts have been routinely used for the resorption of the damaged bone. Nonetheless, rejection of the autografts may hinder their usage [43]. Based on their biomechanical properties, biomaterials are currently employed as substitutes for bone grafts for their potential utilization in structural reconstruction. Later, these engineered scaffolds were tailored to be bioactive and/or bioresorbable to augment the growth of the tissue. The bio-scaffolds being constructed with biodegradable materials are made porous enough to harbor suitable drugs, growth factors, genes, and/or stem cells [44]. Eventually, researchers understood that $\mathrm{Mg}$ metal may be qualified to serve as suitable bone scaffold material to be used in tissue engineering. Furthermore, the $\mathrm{Mg}$ demonstrate enhanced biodegradability, osteogenic effects coupled with superior mechanical strength properties [45]. Several processing techniques like powder metallurgy, additive manufacturing, and laser machining have been used to fabricate $\mathrm{Mg}$ in solid and porous forms [46,47]. Porous $\mathrm{Mg}$ materials synthesized using tissue engineering technique aids in enhancing the biological growth factors or cell attachment on them, thereby making them an ideal scaffold for bone regenerative procedures [48]. According to recent literature, $\mathrm{Mg}$-incorporated composite scaffolds were constructed for bone repair applications, owing to their high antibacterial activity [49].

\section{Biomechanics of Mandible}

The biomechanics of the mandible are greatly influenced by factors such as integrity of the temporomandibular joint (TMJ), bone stock distribution, and forces associated with scar contracture. The reconstruction stages of the mandible should ideally consider the preservation of the joint biomechanics, which could be challenging owing to the complex kinetics of the TMJ. Thus, the process mandates the preservation of the integrity and mechanics of the TMJ at all possible time-points. The infrastructure of the mandible is tailored in such a way that the ascending ramus comprises of the greater density of bone to respond to the forces of mastication. It is often emphasized to always consider the biomechanics of the mandible when attempting to reconstruct the structure. In order to retain the facial symmetry and oral function, one may have to consider maintaining the contour and continuity of the mandible respectively. The mandibular arch anchors the suprahyoid muscles, whereas the mylohyoid muscles are anchored by the body of the mandible, thereby supporting the tongue. Any disruption occurring either at the body of the mandible or the mandibular arch restricts the larynx from being raised during swallowing or affects the tongue position, which ultimately affects the speech, swallowing, and articulation. Misch et al. [50] pointed out that the anterior mandible exhibits a prominent modulus of elasticity and compressive strength, owing to their greater trabecular bone density. The Young's modulus of the trabecular bone is further enhanced due to the presence of the cortical plate, where the anterior mandible bears the highest values. In accordance with his study, the modulus of elasticity ranged from 24.9 to $240 \mathrm{MPa}$ for the cortical bone, with $96.2 \mathrm{MPa}$ as the mean value. The modulus of elasticity and compressive strength of the trabecular bone ranged between 3.5-125.6 MPa and 0.22-10.44 MPa, respectively, when the cortical bone was not considered. The above 
data indicates that the dissipation of a huge amount of occlusal load is rendered by the cortical bone of the mandible. On the other hand, the trabecular bone possesses anisotropic properties [51].

\section{Modular Endoprosthesis}

Modular endoprosthesis reconstruction is a conventional method in limb-sparing surgery in which the diseased bone is removed and replaced with an artificial device [52]. These devices are anchored with bone cement. 15-year survival rates of $94 \%$ reported for endoprosthesis in long bones [53]. Thus, the reconstruction of varied defect sizes could be potentiated by employing a modular system that basically attempts to combine standardized units to allow for the desired flexibility. However, several unique challenges were encountered by the researchers when they progressed to apply this reconstructive method to the mandible. The structure of the mandible is a curved bone with a flat, tear-drop-shaped cross-section, unlike the long bone which is straight with a concentric cross-section. In the case of an alloplastic mandibular reconstruction procedure which necessitates the replacement of the mandibular body, ramus and condyle unit, a mandibular modular endoprosthesis shall serve as a novel method [54]. Endoprosthesis can be described as a metallic device that can be articulated into the medullary space of the mandibular stump post resection that needs no screws for fixation. A locking system can be utilized to connect the modules that bridge the entire length of the bone gap so that it allows for an accurate three-dimensional reconstruction. Traditionally, these stems were cemented into the medullary space with the help of bone cement. Recently, Tideman and Lee [4], in their experimental study on Macaca monkeys, prompted the concept of reconstructing the mandible by employing a modular endoprosthesis. The principle gained popularity and was routinely followed by the orthopedic community for almost a decade. Thus, the literature dictates that such an endoprosthesis can be constructed on the mandible because of the existing medullary space. Animal studies published later detailed the results of replacements of the body of the mandible and ramus/condyle $[4,55]$. Upon scrutiny, the results of these studies revealed that when attempting to replace the body of the mandible, the clinicians encountered prevailing problems such as loosening of the module connections, infection, and loss of peri-implant bone mineral density. The problem faced during condylar/ramus replacement was uneventful healing. They also demonstrated that the endoprosthesis which was designed for replacing the body of the mandible was unable to withstand the masticatory loads, leading to failure [56] (Figure 1). Perhaps clinicians were successful at delivering occlusal rehabilitation supported on the implants that there were anchored by the endoprosthesis. Studies are yet to be done to analyze the applicability of this system for patients with compromised soft tissues and warrants future research to explore this principle.

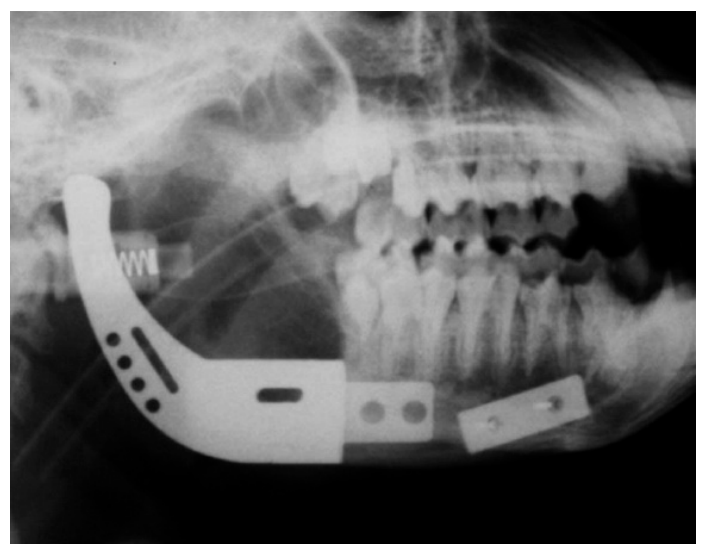

Figure 1. Lateral mandibular radiograph of modular endoprosthesis attached to the mandible. Reproduced with permission from [56], Elsevier, 2019. 


\section{Magnesium/Magnesium Alloys}

Magnesium $(\mathrm{Mg})$ based materials, due to their light weight and excellent combination of specific stiffness and strength, damping behavior, recyclability, thermal stability, and electromagnetic radiation resistance play an important role in a broad variety of structural applications in automobile, aerospace, defense, sports, and consumer electronics industries [57-60]. In the recent past, Mg-based materials for their advantageous properties for medical applications such as biodegradable capacity, good cytocompatibility, favorable mechanical properties, and elastic modulus closer to load bearing bones, unique antibacterial and osteo-promotive properties, have emerged as a new class of biomaterials for orthopedic applications such as implants and fixation devices [61,62]. Mg-based implants share a similar specific density to that of human bone (Table 1), unlike commonly used permanent biomaterials such as stainless steels and titanium alloys [62,63]. Further, in comparison to commercially used orthopedic implants like titanium alloys, stainless steel, and cobalt-chromium (Co-Cr) alloys, $\mathrm{Mg}$ possesses considerably lower elastic modulus matching the elastic modulus of the bone (trabecular/cancellous bones) which aids in eliminating/decreasing any possible stress shielding effects at the bone/implant interface and facilitate new bone formation [64-67]. In addition, $\mathrm{Mg}^{2+}$ is the fourth most abundant cation involved in many chemical reactions in our body, hence establishing its prime importance in the metabolism process [68]. Also, $\mathrm{Mg}$ assists in several antibody formations, alleviating tension in the blood vessels and thereby aiding in regulated muscle contractions. Deficiency in Mg may result in an altered bone structure, leading to reduced osteoblast activity resulting in osteoporosis [69]. One of the main advantages of Mg-based implants over other permanent metal implants is its biodegradability. Owing to its ability to dissolve gradually in the human body and causing minimum/no harm to the host, thereby eliminating the need for implant removal surgeries [69]. These potential factors have eventually given rise to the development of new varieties of magnesium implant materials and recent advancements in alloy development, processing, and fabrication techniques have provided new opportunities to broaden the horizon of Mg utilization in biomedical procedures such as maxillofacial reconstruction, surgical stents, orthopedics, surgical clips, screws, plates, and bone-interface implants [70].

Table 1. Comparative physical property of various orthopedic biomaterials.

\begin{tabular}{ccccccc}
\hline Properties & Human Bone & Magnesium & Titanium Alloy & Co-Cr Alloy & Stainless Steel & Hydroxyapatite \\
\hline Density $\left(\mathbf{g} / \mathrm{cm}^{\mathbf{3}}\right)$ & 1.8 to 2.1 & 1.74 to 2.0 & 4.4 to 4.5 & 8.3 to 9.2 & 8.9 to 8.1 & 3.1 \\
\hline Modulus of Elasticity $(\mathbf{G P a})$ & $3-20$ & $41-45$ & $110-117$ & 230 & $185-205$ & $73-117$ \\
\hline Compressive Strength $(\mathbf{M P a})$ & $130-180$ & $65-100$ & $758-1117$ & $450-1000$ & $170-310$ & 600 \\
\hline Tensile Strength $\left(\mathbf{M P a} \cdot \mathbf{m}^{\mathbf{2}}\right)$ & $3-6$ & $15-40$ & $55-115$ & indeterminate & $50-200$ & 0.7 \\
\hline
\end{tabular}

\section{Magnesium/Magnesium Alloys in Mandibular Reconstruction}

As mentioned earlier, most of the research done so far on performance of Mg-based materials in vivo is performed on long bones such as femurs, tibias, and hip bones [71]. However, flat bones such as mandibles develop differently from long bones, with considerable differences in protein composition and functional differences in formation, resorption, and mechanical properties of the bone types [72]. Further, mandibles endure inconsistent loadings compared to long bones such as tibias. Also, blood flow is another variation which differs depending on the region of the body. Only few studies have reported the performance of degradable Mg-based implants applied to flat-bone repair and this section summarizes the advancements to date in development of Mg-based alloys targeted for mandibular reconstruction.

In order to validate the viability of magnesium alloy implants for mandibular bone repair, Guan et al. [71] implanted Mg-3.1Nd-0.2Zn-0.4Zr alloy (JDBM) with brushite coating (calcium phosphate bio ceramic coating, $\mathrm{CaHPO}_{4} \cdot 2 \mathrm{H}_{2} \mathrm{O}$ ) in-vivo into the rabbit mandible, using $316 \mathrm{~L}$ stainless steel screws as a control group and their subsequent biodegradation and osteogenic effects were investigated. Osteogenesis was evaluated using Van Gieson's picric acid fuchsin. The in-vitro results 
showed increased osteogenic differentiation of rBM-MSC's and in-vivo results showed enhanced osteogenic and osteoconductive potential of the mandibular bone in $\mathrm{Mg}-3.1 \mathrm{Nd}-0.2 \mathrm{Zn}-0.4 \mathrm{Zr}$ alloy with brushite coating (calcium phosphate bio ceramic coating, $\mathrm{CaHPO}_{4} \cdot 2 \mathrm{H}_{2} \mathrm{O}$ ) compared to $316 \mathrm{~L}$ stainless steel screws. A considerable reduction in degradation rate was noticed, mainly because of the brushite coating. The results concluded that bone regeneration and reduction in degradation was enhanced by biodegradable Mg-3.1Nd-0.2Zn-0.4Zr alloy matrix and the brushite coating (Figure 2). In another study, Wang et al. [73] used magnesium alloys for the vertical mandibular distraction of canines. AZ31 magnesium alloys and 316L stainless steel distraction devices were implanted in the canine mandible, and distraction osteogenesis was done at a rate of $0.3 \mathrm{~mm} / 8 \mathrm{~h}$ for 7 days followed by 4 weeks of consolidation. Upon histological evaluation, the harvested specimens demonstrated that more trabecular bone that was formed with active osteoblasts, and mature bone formation was observed in the Mg group compared to the stainless-steel group. Additionally, an increase in height of the mandible with the magnesium group was observed. The vertical height increased from $12.3 \pm 0.2$ to $18.6 \pm 0.2$ in the magnesium group, while in the stainless steel group it increased from $12.1 \pm 0.1$ to $18.6 \pm 0.1$. Thus, the concluding results indicated that magnesium alloys have better bone formation compared to the stainless-steel distraction devices for mandibular reconstruction (Figure 3).
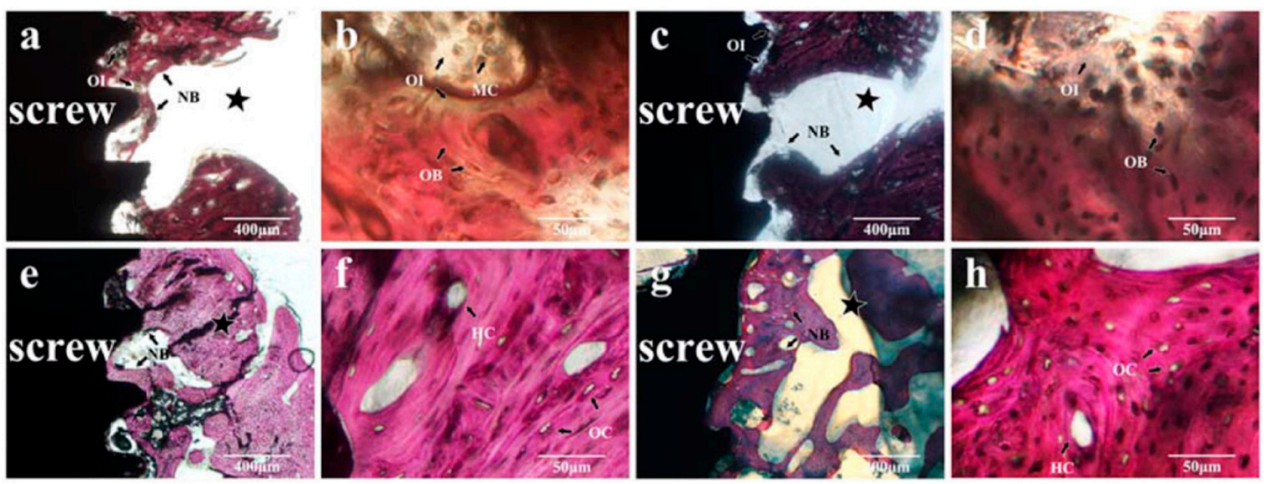

Figure 2. Histological morphologies of implanted C-JDBM (a,b,e,f) and 316L (c, d, g,h) screws and bone tissue after 1 (a-d) and 4 (e-h) months of implantation. NB: new bone, OI: osteoid, MC: multinucleate cell, OB: osteoblast, HC: haversian canal, OC: osteocyte, asterisk: artificial defect. Reproduced with permission from [71], American Chemical Society, 2014.
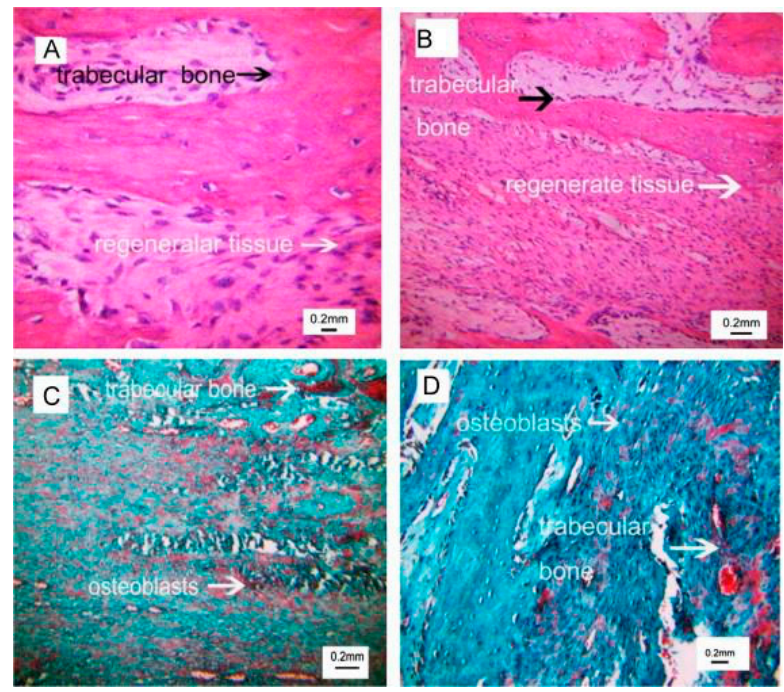

Figure 3. (a) HE staining on the experimental groups, (b) HE staining on the control group, (c) Masson staining on the experimental group, and (d) Masson staining on the control group. Reproduced with permission from [73], Elsevier, 2014. 
Guo et al. in 2018 [74] evaluated the repair of alveolar bone with mineralized collagen (MC) block reinforced with $\mathrm{Mg}-\mathrm{Ca}$ alloy in the buccal plates of canines. The Mg-Ca-MC composite and pure MC blocks were implanted on the buccal plates of the mandible bilaterally, and the bone regeneration was evaluated at the 12th week and 24th-week post-implantation. Both the groups depicted new bone formation at the end of the 12th week, but there was not much difference between the two groups. At the end of 24 weeks both groups displayed increased bone volume and total volume, but for the $\mathrm{Mg}$-Ca-MC group the newly formed bone was denser and more compact compared to the MC group. The authors concluded that the Mg composites accelerated the growth of new bone and repaired the alveolar ridge of the buccal bone defect. Lee et al. in 2017 [75] constructed the finite element analysis model for sagittal split ramus osteotomy of the mandible to study and compare the stability of biodegradable magnesium alloy screws with absorbable polymers and titanium screws. The stress distribution of magnesium, polylactic acid polymer, and titanium were evaluated by applying an occlusal load ranging from $132 \mathrm{~N}$ to $1000 \mathrm{~N}$. The maximum stress was seen to be concentrated on the mandibular condylar neck and the sigmoid notch of the proximal segment in cortical bone, which was recorded as $83.49 \mathrm{MPa}$. A similar pattern of stress distribution of 7.87 MPa was exhibited by the cancellous bone. In the triangular configuration of titanium screws, the maximum stress was 129.95 MPa and mainly concentrated on the screw head and proximal part, which was engaged in the proximal segment of the mandible. In the proximal segment, the maximum stress was concentrated on the condylar neck and sigmoid notch. The maximum stress on the cortical bone was $83.53 \mathrm{MPa}$ in the triangular configuration, $88.38 \mathrm{MPa}$ in the reinforced triangular configuration, and $92.55 \mathrm{MPa}$ in the linear configuration. The maximum stress on the polymer screw was $7.19 \mathrm{MPa}, 8.77 \mathrm{MPa}$, and $9.65 \mathrm{MPa}$ in the triangular, reinforced triangular, and linear configurations, respectively. The distribution of stress on the mandible in the $\mathrm{Mg}$ screw system was like that of other material groups, with stress distributed on the condylar neck and sigmoid notch regardless of the positioning configurations. Maximum stress on the cortical bone was $83.49 \mathrm{MPa}$, 88.26 MPa, and 92.46 MPa in the triangular, reinforced triangular, and linear configurations, respectively. Maximum stress on the screw was 85.54 MPa, 73.09 MPa, and 85.31 MPa in the triangular, reinforced triangular, and linear configurations, respectively. The stress was less converged on the cortical bone in the triangular and reinforced triangular models, and the stress was also less converged on the cortical bone when compared with the linear configuration model. The stress concentrated on the screws was evenly distributed in the screw unit, compared to the polymer screw system model in the triangular and reinforced triangular configurations. By that, the results emphasized that $\mathrm{Mg}$ alloy was able to distribute the stress evenly to the other biological components of the mandible like the condyle and ramus when compared to the polymer group. There was a minimum deformation of less than $0.2 \mathrm{~mm}$ at the initial functional loading for all three groups. The magnesium alloy screws were proven to take up further stress, and thereby decreased the deleterious effect on the stability of the sagittal split ramus (Figures 4-6 and Table 2).

Table 2. Maximum von Mises stress under the given conditions (MPa). Reproduced with permission from [75], Elsevier, 2017.

\begin{tabular}{cccccccc}
\hline Component & Titanium T & Polymer 1 T & Polymer 2 RT & Polymer 3 L & Mg 1 T & Mg 2 RT & Mg 3 L \\
\hline Cortical & 83.49 & 83.53 & 88.38 & 92.55 & 83.49 & 88.26 & 92.46 \\
\hline Cancellous & 7.87 & 7.88 & 9.06 & 7.98 & 7.87 & 9.04 & 7.97 \\
\hline Screw & 129.95 & 7.19 & 8.77 & 9.65 & 85.54 & 73.09 & 85.31 \\
\hline
\end{tabular}



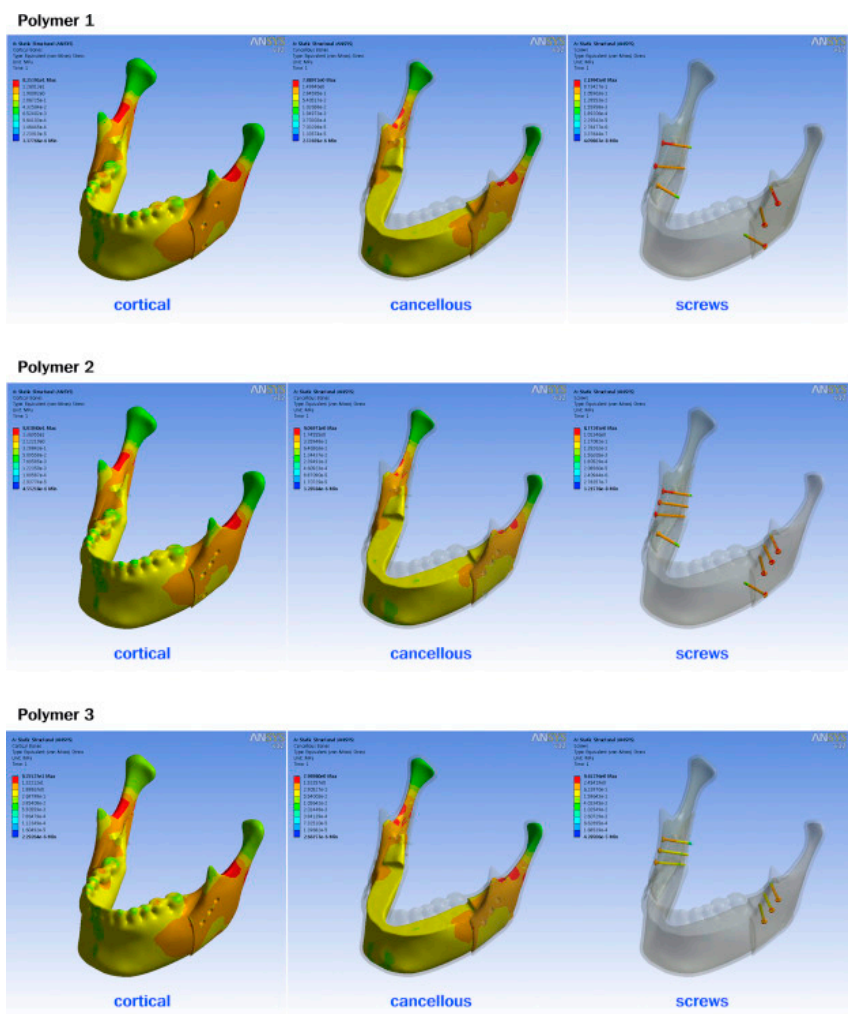

Figure 4. The distribution of stress in polymer screws according to different screw configurations: 1-triangular, 2-reinforced triangular, 3-linear. Reproduced with permission from [75], Elsevier, 2017.
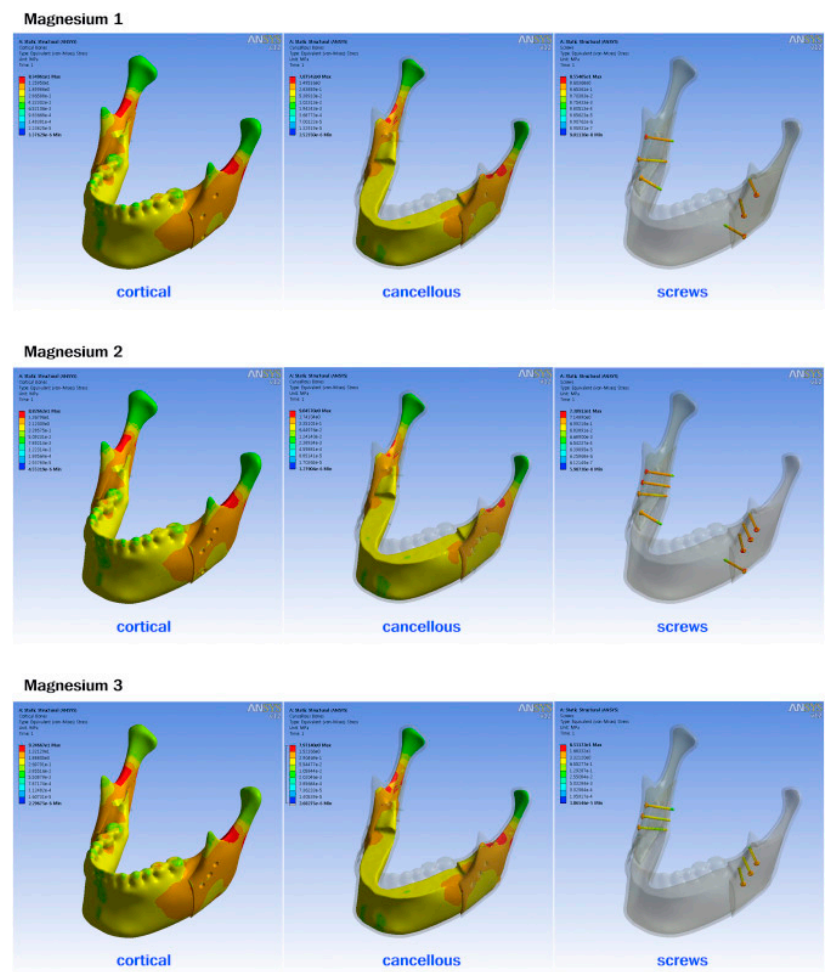

Figure 5. The distribution of stress in magnesium alloy screws according to different screw configurations: 1-triangular, 2-reinforced triangular, 3-linear. Reproduced with permission from [75], Elsevier, 2017. 


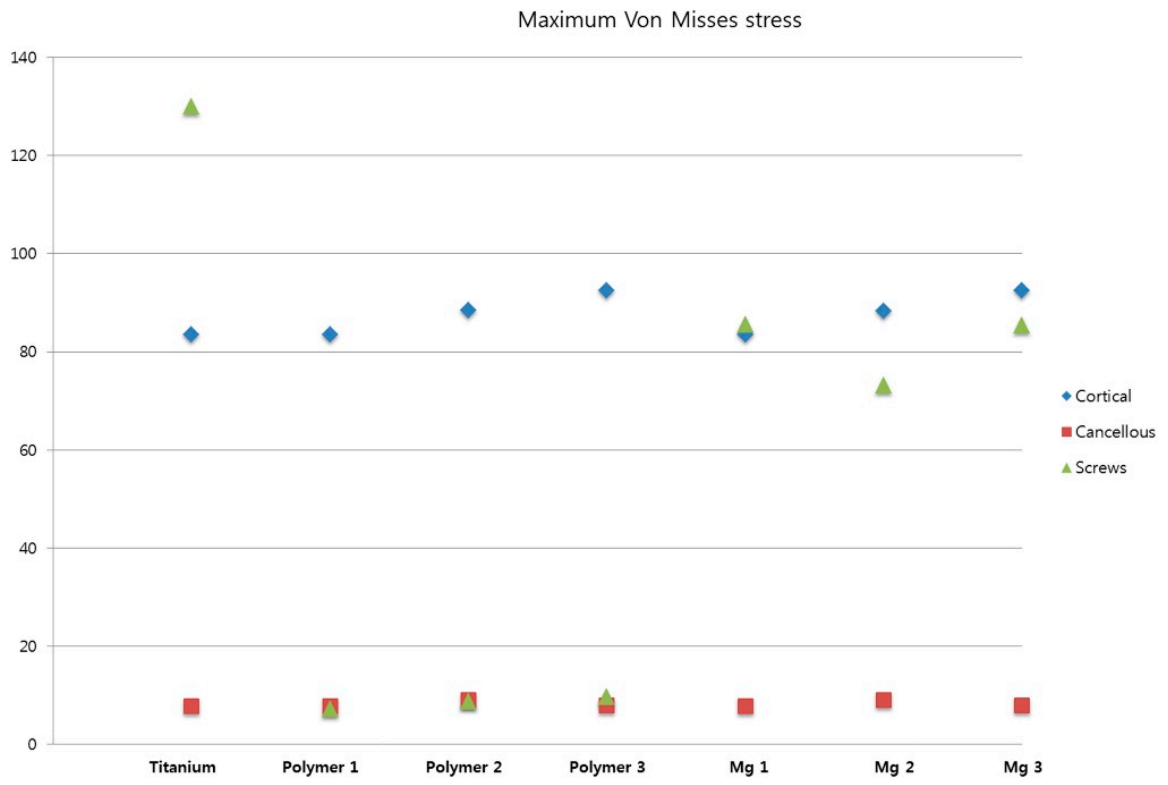

Figure 6. Maximum von Mises stress in each component of the model. Reproduced with permission from [75], Elsevier, 2017.

Wang et al. in 2018 [76] investigated the osteogenic effect of $\mathrm{Mg}-\mathrm{Sr}$ on the bone defect of mandibular canines. Mg-Sr was implanted on the mandibular buccal fenestration bone defect of canines after extraction of the second and 3rd premolar. The Mg-Sr scaffolds were compared to the mineralized collagen. The results showed that the bone volume and thickness of woven bone were higher in the $\mathrm{Mg}$-Sr group compared to the mineralized collagen group, indicating $\mathrm{Mg}$-Sr scaffolds had more osteogenic potential when implanted in the mandibular defects of canines.

\section{Challenges of Mg-Based Biomaterials in Clinical Applications}

Despite their advantages, several technical challenges have been encountered by researchers that apparently impede the clinical applicability of biodegradable $\mathrm{Mg}$ and its alloys and composites. Firstly, early loosening or disintegration of the implants before the tissue has sufficiently healed occurs when pure $\mathrm{Mg}$ and some of its alloys corrode too quickly under physiological conditions $[77,78]$. Besides, the hydrogen gas released rapidly during the corrosion process appears to be too swift to be dealt with by the host tissue [77]. Furthermore, $\mathrm{Mg}$ and its alloys are extremely susceptible to inhomogeneous and localized degradation, resulting in a local concentration of stress and disintegration of mechanical strength, eventually increasing the vulnerability of the implants to an unexpected fracture way before the anticipated lifetime [61]. Lastly, the ductility and strength of magnesium and its alloys are yet to be enhanced for specific applications to attain optimal in-vivo performance [79]. Thus, addressing these short-comings can give way to the development of novel bio-Mg alloys that can be targeted as a futuristic goal for research work in medical applications and to be later transformed for clinical use. The following concerns need to be addressed when designing the biomaterial:

1. Biosafety and biocompatibility: Elements such as $\mathrm{Al}$ and Be have been identified as neurotoxic [68] and should preferably be avoided for alloying, as they are not suitable candidates for biomedical applications.

2. Requisite strength and ductility: As for orthopedic implants, materials possessing yield strength of $>200 \mathrm{MPa}$, elongation $>10 \%$, and a degradation rate $<0.5 \mathrm{~mm} / \mathrm{y}$ in simulated fluids at $37^{\circ} \mathrm{C}$, ensures a productive lifetime of 90-180 days; whereas, for cardiovascular stents, higher ductility and moderate strength are desirable for cardiovascular stents, with elongation $>20 \%$ [80]. 
3. Uniform degradation: Most studied magnesium alloys are highly susceptible to localized corrosion [61]. Regardless, uniform and controllable degradation characteristics are essential for accurate predictions of an implant serving its lifetime. Also, $\mathrm{Mg}$ has a high negative standard electrode potential which leads to the rapid corrosion of Mg-based alloys in chloride physiological conditions producing $\mathrm{Mg}(\mathrm{OH})_{2}$ and $\mathrm{H}_{2}$ gas. Pure $\mathrm{Mg}$ dissolves in physiological solutions through the following electrochemical reactions [62]:

$$
\begin{gathered}
\mathrm{Mg} \rightarrow \mathrm{Mg}^{2+}+2 \mathrm{e}^{-} \\
2 \mathrm{H}_{2} \mathrm{O}+2 \mathrm{e}^{-} \rightarrow \mathrm{H}_{2} \uparrow+2 \mathrm{OH}^{-} \\
\mathrm{Mg}^{2+}+2 \mathrm{OH}^{-} \rightarrow \mathrm{Mg}(\mathrm{OH})_{2}
\end{gathered}
$$

$\mathrm{Mg}(\mathrm{OH})_{2}$ deposited over the entire surface can act as a passive layer or kinetic barrier which prevents the further migration of ions or chemical reactions across the metal surface. However, $\mathrm{Mg}(\mathrm{OH})_{2}$ starts to convert into highly soluble magnesium chloride $\left(\mathrm{MgCl}_{2}\right)$, particularly in the presence of chloride ions that subsequently lead to the pitting corrosion [64]:

$$
\mathrm{Mg}(\mathrm{OH})_{2}+2 \mathrm{Cl}^{-} \rightarrow \mathrm{MgCl}_{2}+2 \mathrm{OH}^{-}
$$

Additionally, hydrogen gas produced at a high rate from corrosion cannot be dealt with by the host tissue which has delayed the introduction of $\mathrm{Mg}$ based materials for therapeutic applications to date [64]. Further, shift in alkaline $\mathrm{pH}$ in the region surrounding the corroding surface is also a concern for biomedical applications. Therefore, development of $\mathrm{Mg}$ alloys with improved corrosion behavior may help to resolve the current limitations in Mg alloys to be used as a biomaterial.

4. Cost effective eco-friendly production technique: Design and development of the biomaterial economically-conscious processing methodologies by the usage of eco-friendly protective gases like argon (Ar) over greenhouse cases like sulfur hexafluoride $\left(\mathrm{SF}_{6}\right)$ to synthesize the material [58]. Disintegrated melt deposition and microwave sintering assisted powder metallurgy techniques can be identified as suitable processes for the primary synthesis of the biomaterial [58]. Incorporation of these processes will go a long way in reducing the cost of the technology and eventual cost borne by the end user.

The aforementioned factors are greatly interconnected in terms of the design and engineering of Mg alloys. Thus, the plausible challenges faced in the development of novel bio-Mg includes choosing a biocompatible alloying element to attain compatible mechanical properties, besides ensuring controllable degradation through alloy composition design and microstructure design and control. Researchers have also attempted few techniques to upgrade the corrosion resistance of $\mathrm{Mg}$ alloys. Thus, considering the need to improve the mechanical and electrochemical properties of the alloy, researchers strive to optimize the right composition of the alloying elements $(\mathrm{Zn}, \mathrm{Ca}, \mathrm{Si}, \mathrm{Gd}, \mathrm{Mn}$, $\mathrm{Zr}, \mathrm{Li}$ and so on) used in the metal matrix with the hope of reducing the costs of production and possible impurities in the developed alloy systems. Besides, strategies such as surface modification, coating of the magnesium alloys with a corrosion resistant yet bioactive element that could potentiate bone formation (e.g., Ca-P coatings) can also be adopted. Literature demonstrates few such reports where the authors have tried to coat the Mg alloys. Few studies incorporated the use of Ca-P coatings to enhance the corrosion resistance of these alloys and reported poorer mechanical properties and decreased adhesion to the $\mathrm{Mg}$ alloy, resulting in delamination [81].

\section{Methods to Enhance the Corrosion Resistance of Magnesium and its Alloys}

Enhancing the corrosion resistance and the mechanical properties of the $\mathrm{Mg}$ matrix are the significant requisites of the biocompatible elements used for alloying. Whenever $\mathrm{Mg}$ alloys are being employed for clinical use to serve as fixators, they must render resilience against bone fractures in the 
first 3 months post-surgery [82]. Thus, it is ideal to ensure that they maintain their mechanical integrity during the early stages of implantation. Unlike alloying, with surface modification, the surface of the $\mathrm{Mg}$ matrix that contacts the body fluids can be effectively isolated or reduced. This in turn can facilitate the maintenance of the mechanical integrity of $\mathrm{Mg}$ implants until the period of complete fracture healing [83,84]. Thus, surface treatment could be a potential methodology to restrain the degradation rate of $\mathrm{Mg}$ metals for implantation. Numerous surface coating protocols exist of which the Ca-P coatings encompasses certain chemical components that mimic the mineral component of mammalian bones and are the most frequently used for modifying the $\mathrm{Mg}$ surface, owing to their excellent biocompatibility [85]. Besides Ca-P coating, another significant alternative would be oxide coating for upgrading the corrosion resistance of the metal [86-89]. Micro-arc oxidation (MAO) imposes a significant amount of metallurgical binding strength to $\mathrm{Mg}$ and $\mathrm{Mg}$ alloys substrate, thereby aiding in oxide coating. Depending on the chemical composition of the electrolytic bath, the protective coating comprises mainly of $\mathrm{MgO}$ combined with $\mathrm{Mg}$ phosphate, silicates, and so on. Another chemical conversion method to enhance the corrosion resistance of $\mathrm{Mg}$ and its alloys is fluoride treatment $[90,91]$. Moreover, biodegradable polymer coating serves as a promising methodology to resist the initial corrosion of Mg-based materials, thereby allowing the bone tissues to heal adequately [92,93]. Literature validates the use of materials such as poly (lactic-co-glycolic acid) (PLGA), polycaprolactone (PCL) and chitosan for clinical use in humans. Thus, when these materials are treated with the aid of potential surface treatment technologies, the corrosion resistance can greatly be enhanced. Biodegradable implants such as Mg-based orthopedic implants or devices are considered unique, owing to their property of being able to maintain their mechanical integrity throughout the duration of bone fracture healing. The abovementioned statement only holds true when the degradation of the material is controlled such that the material degrades only after the bone healing is fully complete. Hence, critical design and development of unique $\mathrm{Mg}$ based biomedical alloys using biocompatible alloying elements and nanoparticles is of the utmost importance to meet this requirement for controlled degradation without causing adverse effects to the host body. Despite the techniques attempting to render them corrosion resistant, one should also consider employing techniques such as surface coating, alloying, or a nanocomposite approach during the early phases which might improve the effectiveness of the implant. Additionally, it may also mask the useful effects of the $\mathrm{Mg}^{2+}$ ions during bone regeneration. On the contrary, literature presents long-term studies that emphasize effects of $\mathrm{Mg}$ degradation on healed, fractured bone, that fails to explain how long term degradation can potentiate faster remodeling of bone and enhance their mechanical properties. Incorporation of biomimetic surface treatment methods to enhance the corrosion protection of $\mathrm{Mg}$-based materials in physiological liquids could be a great approach to subside the issues of $\mathrm{Mg}$ in chloride environments and superiorly enhance its applicability in the clinical field.

\section{Current Research on Nanocomposites as Orthopaedic Materials and Future of Mg-Based Nanocomposites in the Field of Mandibular Reconstruction}

Bone is a natural nanocomposite with nano-hydroxyapatite (HA) particles dispersed in a collagen matrix. The collagen matrix provides necessary energy absorption to the bones and prevents sudden failures, while the hydroxyapatite is a high strength ceramic providing the necessary load bearing [94]. Additionally, nano-HA affects high protein absorption and thy subsequent osteoblast activity. Implant materials with properties physiologically like the bone would assist in the easy formation of new bone at the implant/tissue interface $[95,96]$. Several studies on ceramic based polymer nanocomposites for orthopedic applications are available in the open literature. Liu et al. reported that the addition of nano-titania to polylactide-co-glycolide (PLGA) matrix enhanced the osteoblast adhesion and calcium mineral deposition compared to pure PLGA [97]. Superior initial protein adsorption leading to enhanced osteoblast addition was observed in polylactide (PLA) with the addition of nanophase HA particles. The performance of HA-PLA nanoporous scaffolds was better than HA-PLA microporous scaffolds highlighting the effect of the size of the secondary phase [98]. Further, in a similar study, 
reducing the size of alumina from $167 \mathrm{~nm}$ to $24 \mathrm{~nm}$ resulted in a $\sim 51 \%$ enhancement and $\sim 235 \%$ decrement in osteoblast and fibroblast adhesion, respectively, after $4 \mathrm{~h}$ [99]. Not only do nanophase ceramics enhance the biocompatibility of the material, but they can also be used to greatly improve the mechanical properties (hardness, bending, compression and tensile) of the material. The higher surface volume of the nanoparticles compared to micron/millimeter-sized secondary phases result in increased deformation owing to short-range diffusion and grain boundary sliding events that result in reduced grain size and improved ductility properties. Also, the higher wettability of the nanosized secondary phases with the matrix make it more compatible for use in comparison to reinforcements of coarser sizes [100]. Poly (l-lactic acid) (PLLA) was used with MgO and HA nanoparticles and a comparative study on the mechanical, antibacterial, cell adhesion properties was carried out. PLLA/MgO nanocomposites displayed superior antibacterial properties compared to PLLA/HA nanocomposites. PLLA/MgO nanocomposites showed increased cell viability and proliferation of fibroblasts and osteoblasts when compared to PLLA and PLLA/HA nanocomposites. However, the mechanical properties were compromised, leading to increased modulus of elasticity and reduced material elasticity [101]. Although polymer matrix ceramic nanocomposites display superior improved antibacterial and biocompatible properties, limited load bearing properties restrict its widespread application in mandibular reconstruction and other maxillo-facial implants. In order to address this concern, biodegradable metal matrix ceramic nanocomposites could be a possible solution as they display superior mechanical properties and with optimal design can display superior biocompatibility matching the physiological bone.

Alloying magnesium with biocompatible elements (like $\mathrm{Zn}, \mathrm{Ca}, \mathrm{Ag}, \mathrm{Sr}, \mathrm{Dy}, \mathrm{Li}$ ) and surface treatment of the materials with coatings (MAO, CVD) are identified to be an excellent approach in order to improve its mechanical and anti-corrosion properties [83]. However, these processes might lead to increased costs in terms of additional time and energy. Also, the unique intrinsic property of each alloying element and its compatibility with the Mg matrix is characteristically different [102,103]. In order to circumvent the issue of non-versatility, composite technology can be employed by adding low volume inexpensive biocompatible ceramic reinforcements (preferably in nano length scale) in order to tailor the mechanical (hardness, tensile, compressive) properties and biomechanical (corrosion, Young's modulus) properties as per the requirement of the implant. Recent studies in the field of $\mathrm{Mg}$ nanocomposites have shown a significant reduction in the grain size of $\mathrm{Mg}$ with the incorporation of biocompatible reinforcements [104,105]. Smaller grain sizes result in a higher number of grain boundaries leading to higher energies. Thus, increased chemical activities lead to increased surface reactivities, thereby creating a protective layer by alleviating the extent of localized corrosion [106]. Nanosized secondary phases have higher surface areas with increased surface and edge defects influencing biological reactions such as protein adsorption and cell adhesion. These reactions are possible due to the unique surface roughness properties of the nanophases as a result of their reduced grain size, crystallinity (texture), and micro porosity [106]. Several metal oxides, carbides, nitrides, and borides at nano-length scales have been successful in improving the mechanical and anti-corrosion properties of monolithic magnesium [66,107]. Ong et al. [108] studied the effect of titanium (in oxide, carbide and nitride form) on the cytotoxicity response of pure magnesium. It was observed that an addition of 2.5 vol. $\% \mathrm{TiO}_{2}, \mathrm{TiN}$, and $\mathrm{TiC}$ nanoparticles had little to no effect on the cytotoxicity behavior of Mg matrix. Murine-derived preosteoblast cell line (MC3T3-E1) was used in this study for indirect cytotoxicity assays. Khalajabadi et al. [109] studied the effect of $\mathrm{MgO}$ and $\mathrm{MgO} / \mathrm{Si}$ coating on the corrosion resistance and cytocompatibility of $\mathrm{Mg} / \mathrm{HA} / \mathrm{TiO}_{2}$ nanocomposites synthesized using powder metallurgy route. Cell viability of $\sim 73 \%$ in the uncoated form was increased to $\sim 88 \%$ with the $\mathrm{MgO} / \mathrm{Si}$ coating post nine days of incubation, highlighting a good degree of cytocompatibility in vitro [110].

The reinforcement phases like hydroxyapatite, tricalcium phosphate, fluorapatite, and calcium polyphosphate could also be used in the $\mathrm{Mg}$ matrix either individually or in a hybrid form to develop biodegradable magnesium matrix nanocomposites with enhanced mechanical properties 
and controlled degradation rate. Presence of calcium in the form of supplements could also assist with osteoblast activity, leading to easier bone remodeling activity [68,110]. Prakash et al. [111] studied the effect of $\mathrm{Si}$ and $\mathrm{HA}$ addition to the corrosion resistance and in vitro bioactivity behavior of Mg-Zn-Mn alloy using MG-63 osteoblast cells. With increased incubation times, Mg-Zn-Mn-(Si-HA) bio composite showed increased cell and proliferation when compared to $\mathrm{Mg}-\mathrm{Zn}-\mathrm{Mn}$ alloy. Reinforcing HA accentuated a strong positive impact on the apatite layer formation and bioactivity of the developed implant material. Biocompatible phases like $\mathrm{Mg}_{2} \mathrm{Si}, \mathrm{Mn}-\mathrm{CaO}, \mathrm{Mn}_{5} \mathrm{Si}_{3}, \mathrm{CaMgSi}, \mathrm{MnSi}$, and $\mathrm{CaMgZn}$ were formed spontaneously, providing a biomimetic layer formation on the alloy which expedited the bone adhesion, cell adhesion, cell growth, and proliferation of the MG-63 osteoblast cell line. The research on Mg-matrix bio composites is still in its infant stage and there is immense potential untapped in this area that needs to be further explored by more multidisciplinary research between developmental material scientists and clinical physicians.

Nanocomposite technology could be a fruitful approach to design next generation implant materials using soft $\mathrm{Mg}$ matrix with nano-dimensional structures incorporated to bio-mimic a natural bone. However, extensive optimization of the Mg-based nanocomposites is essential for the widespread acceptance of these materials as potential implants for mandibular reconstruction. Importantly, translating the enhanced mechanical properties and anti-corrosive properties to successful in vitro, in vivo, animal trials, and clinical studies is crucial for understanding the viability of these implants from an effectiveness, safety, and commercial standpoint.

\section{Conclusions and Future Scope}

In the recent past of biomedical research, surgical components such as screws, plates, wires, and temporary devices have gained popularity to mitigate the need for second surgeries following bone healing. Mg being a biodegradable material possessing excellent compatibility with human bone, has gained immense popularity as a material of choice in the construction of temporary implants. Magnesium degrades to $\mathrm{Mg}^{2+}$ ions, which is a crucial step for undergoing metabolism in the human body. Nonetheless, the high degradation rate of $\mathrm{Mg}$ in physiological conditions do not allow it to be readily considered for implants. Hence, researchers and clinicians are keen on exploring the possibilities of utilizing $\mathrm{Mg}$ based alloys despite their limited clinical applicability as per available literature. When the implants are clinically loaded, they happen to encounter tremendous amounts of varied acute loadings. Thus, in order to withstand these forces, the Mg alloys will have to possess adequate cracking and corrosion resistance against the destructive effects of corrosive human fluids. Biomedical research did venture on to investigate some of the properties such as corrosion assisted cracking resistance of the $\mathrm{Mg}-\mathrm{Al}$ alloys. Subsequent results have concluded that $\mathrm{Mg}-\mathrm{Al}$ alloys are not suitable candidates to be incorporated in biomedical devices because of the detrimental effects of $\mathrm{Al}$ during its long term exposure. Thus, in order to transcend the implementation of $\mathrm{Mg}$ and its novel alloys into clinical applications, their resistance against corrosion assisted cracking needs to be validated.

Besides, it has also been established that the hydrogen evolution which occurs during the $\mathrm{Mg}$ dissolution in aqueous solutions accounts for a deleterious effect on the biocompatibility. It was observed that the amount of hydrogen produced cannot be absorbed by the human body whenever the corrosion rate was enormous, resulting in the formation of gas bubbles at the bone/tissue interface. This accumulation of gas bubbles, concentrated in a region, might lead to abrupt implant failures. Although molecular hydrogen has been recently identified as a novel therapeutic antioxidant capable of selectively reducing toxic reactive-oxygen species [112]. Furthermore, corrosion of magnesium alloys in an aqueous solution results in anodic dissolution of $\mathrm{Mg}$ in the form of $\mathrm{Mg}^{2+}$ into the solution. This $\mathrm{Mg}^{2+}$ reacts with the hydroxide $\left(\mathrm{OH}^{-}\right)$and chloride $\left(\mathrm{Cl}^{-}\right)$ions from the solution accounting for an increase in the $\mathrm{pH}$ of the surrounding solution, eventually having a degradative action on cell proliferation. 
Thus, as part of the efforts taken to combat the corrosive properties of these alloys, significant requisites would be the introduction of newer coating techniques and biocompatible surfaces in the future. It shall be envisioned that the key research would revolve around the studies to optimize the corrosion behavior and corrosion assisted cracking resistance of $\mathrm{Mg}$ and its alloys' when surface coated with biocompatible coatings such as $\mathrm{TiO}_{2}, \mathrm{TiC}$ and $\mathrm{TiN}$ [113]. Futuristic goals would dwell on theories namely, device production processes and their effect on corrosion resistance. Researchers may consider grain refinement as one other successful strategy. A study by Song and Atrens [114] demonstrated that finer grains allow a nearly continuous distribution of second phases, leading to a corrosion delay as corrosion products remain near the $\mathrm{Mg}$ matrix, and act as barrier. Moreover, finer grains enhance the corrosion assisted cracking resistance by inhibiting crack initiation and dislocations motion that ultimately leads to an increase in the number of barriers to crack propagation [115]. Few of such related production processes that lead to finer grains are hot deformation and rapid solidification, amongst others. Thus, a comprehensive exploratory research that can investigate in detail the property of rapid solidification processes to increase the solubility of the alloying elements would be desirable. Nonetheless, it may be noted that magnesium based orthopedic implants (headed and headless screws) are currently being marketed by companies in Germany and South Korea with successful human trials.

Author Contributions: S.P., V.M. and G.P. outlined the review, performed the literature search and wrote the manuscript. V.R. and R.W. helped in compiling the wide information related to the topic and data presentation and performed technical editing for all corrections. M.G. also helped in writing the manuscript and developed the idea of the topic and was responsible for the correspondence.

Funding: This work was supported by National University of Singapore, grant No. R-221-000-092-133.

Conflicts of Interest: The authors declare no conflict of interest.

\section{References}

1. Chim, H.; Salgado, C.J.; Mardini, S.; Chen, H.-C. Seminars in Plastic Surgery; Thieme Medical Publishers: New York, NY, USA, 2010; p. 188.

2. Hadlock, T.A.; Vacanti, J.P.; Cheney, M.L. Tissue engineering in facial plastic and reconstructive surgery. Facial Plast. Surg. 1998, 14, 197-203. [CrossRef] [PubMed]

3. Lee, S.; Goh, B.; Tideman, H.; Stoelinga, P. Modular endoprosthesis for mandibular reconstruction: A preliminary animal study. Int. J. Oral Maxillofac. Surg. 2008, 37, 935-942. [CrossRef] [PubMed]

4. Lee, S.; Goh, B.; Tideman, H.; Stoelinga, P.; Jansen, J. Modular endoprosthesis for mandibular reconstruction: A clinical, microcomputed, tomographic and histologic evaluation in 8 Macaca fascicularis. Int. J. Oral Maxillofac. Surg. 2009, 38, 40-47. [CrossRef] [PubMed]

5. Wong, R.; Lee, S.; Tideman, H.; Merkx, M.; Jansen, J.; Liao, K. Effect of replacement of mandibular defects with a modular endoprosthesis on bone mineral density in a monkey model. Int. J. Oral Maxillofac. Surg. 2011, 40, 633-639. [CrossRef] [PubMed]

6. Bondarenko, A.; Hewicker-Trautwein, M.; Erdmann, N.; Angrisani, N.; Reifenrath, J.; Meyer-Lindenberg, A. Comparison of morphological changes in efferent lymph nodes after implantation of resorbable and non-resorbable implants in rabbits. Biomed. Eng. Online 2011, 10, 32. [CrossRef] [PubMed]

7. Duygulu, O.; Kaya, R.A.; Oktay, G.; Kaya, A.A. Investigation on the potential of magnesium alloy AZ31 as a bone implant. Mater. Sci. Forum 2007, 546-549, 421-424. [CrossRef]

8. Erdmann, N.; Angrisani, N.; Reifenrath, J.; Lucas, A.; Thorey, F.; Bormann, D.; Meyer-Lindenberg, A. Biomechanical testing and degradation analysis of $\mathrm{MgCa} 0.8$ alloy screws: A comparative in vivo study in rabbits. Acta Biomater. 2011, 7, 1421-1428. [CrossRef] [PubMed]

9. Erdmann, N.; Bondarenko, A.; Hewicker-Trautwein, M.; Angrisani, N.; Reifenrath, J.; Lucas, A.; Meyer-Lindenberg, A. Evaluation of the soft tissue biocompatibility of $\mathrm{MgCa} 0.8$ and surgical steel 316L in vivo: A comparative study in rabbits. Biomed. Eng. Online 2010, 9, 63. [CrossRef] [PubMed]

10. Hampp, C.; Ullmann, B.; Reifenrath, J.; Angrisani, N.; Dziuba, D.; Bormann, D.; Seitz, J.M.; Meyer-Lindenberg, A. Research on the biocompatibility of the new magnesium alloy LANd442-An in vivo study in the rabbit tibia over 26 weeks. Adv. Eng. Mater. 2012, 14, B28-B37. [CrossRef] 
11. Hampp, C.; Angrisani, N.; Reifenrath, J.; Bormann, D.; Seitz, J.-M.; Meyer-Lindenberg, A. Evaluation of the biocompatibility of two magnesium alloys as degradable implant materials in comparison to titanium as non-resorbable material in the rabbit. Mater. Sci. Eng. C 2013, 33, 317-326. [CrossRef] [PubMed]

12. Huehnerschulte, T.A.; Reifenrath, J.; von Rechenberg, B.; Dziuba, D.; Seitz, J.M.; Bormann, D.; Windhagen, H.; Meyer-Lindenberg, A. In vivo assessment of the host reactions to the biodegradation of the two novel magnesium alloys ZEK100 and AX30 in an animal model. Biomed. Eng. Online 2012, 11, 14. [CrossRef] [PubMed]

13. Janning, C.; Willbold, E.; Vogt, C.; Nellesen, J.; Meyer-Lindenberg, A.; Windhagen, H.; Thorey, F.; Witte, F. Magnesium hydroxide temporarily enhancing osteoblast activity and decreasing the osteoclast number in peri-implant bone remodeling. Acta Biomater. 2010, 6, 1861-1868. [CrossRef] [PubMed]

14. Kim, S.M.; Jo, J.H.; Lee, S.M.; Kang, M.H.; Kim, H.E.; Estrin, Y.; Lee, J.H.; Lee, J.W.; Koh, Y.H. Hydroxyapatite-coated magnesium implants with improved in vitro and in vivo biocorrosion, biocompatibility, and bone response. J. Biomed. Mater. Res. Part A Off. J. Soc. Biomater. Jpn. Soc. Biomater. Aust. Soc. Biomater. Korean Soc. Biomater. 2014, 102, 429-441.

15. Krause, A.; von der Höh, N.; Bormann, D.; Krause, C.; Bach, F.-W.; Windhagen, H.; Meyer-Lindenberg, A. Degradation behaviour and mechanical properties of magnesium implants in rabbit tibiae. J. Mater. Sci. 2010, 45, 624. [CrossRef]

16. Li, Z.; Gu, X.; Lou, S.; Zheng, Y. The development of binary Mg-Ca alloys for use as biodegradable materials within bone. Biomaterials 2008, 29, 1329-1344. [CrossRef] [PubMed]

17. Meyer-Lindenberg, A.; Thomann, M.; Krause, A.; Bormann, D.; Rechenberg, B.V.; Windhagen, H. Untersuchungen zum Einsatz einer Magnesiumbasislegierung als neues resorbierbares Implantatmaterial für die Osteosynthese. Kleintierpraxis 2010, 55, 349-363.

18. Thomann, M.; Krause, C.; Bormann, D.; von der Höh, N.; Windhagen, H.; Meyer-Lindenberg, A. Comparison of the resorbable magnesium. alloys LAE442 und MgCa0.8 concerning their mechanical properties, their progress of degradation and the bone-implant-contact after 12 months implantation duration in a rabbit model. Mater. Und Werkst. Entwickl. Fert. Prüfungeigenschaften Und Anwend. Tech. Werkst. 2009, 40, 82-87. [CrossRef]

19. Thomann, M.; Krause, C.; Angrisani, N.; Bormann, D.; Hassel, T.; Windhagen, H.; Meyer-Lindenberg, A. Influence of a magnesium-fluoride coating of magnesium-based implants ( $\mathrm{MgCa} 0.8)$ on degradation in a rabbit model. J. Biomed. Mater. Res. Part A Off. J. Soc. Biomater. Jpn. Soc. Biomater. Aust. Soc. Biomater. Korean Soc. Biomater. 2010, 93, 1609-1619. [CrossRef] [PubMed]

20. Höh, N.V.D.; Bormann, D.; Lucas, A.; Denkena, B.; Hackenbroich, C.; Meyer-Lindenberg, A. Influence of different surface machining treatments of magnesium-based resorbable implants on the degradation behavior in rabbits. Adv. Eng. Mater. 2009, 11, B47-B54. [CrossRef]

21. Von der Höh, N.; Bormann, D.; Lucas, A.; Thorey, F.; Meyer-Lindenberg, A. Comparison of the in vivo degradation progress of solid magnesium alloy cylinders and screw-shaped magnesium alloy cylinders in a rabbit model. Mater. Sci. Forum 2010, 638, 742-747. [CrossRef]

22. Von der Höh, N.; von Rechenberg, B.; Bormann, D.; Lucas, A.; Meyer-Lindenberg, A. Influence of different surface machining treatments of resorbable magnesium alloy implants on degradation-EDX-analysis and histology results. Mater. Und Werkst. Entwickl. Fert. Prüfungeigenschaften Und Anwend. Tech. Werkst. 2009, 40, 88-93. [CrossRef]

23. Willbold, E.; Kalla, K.; Bartsch, I.; Bobe, K.; Brauneis, M.; Remennik, S.; Shechtman, D.; Nellesen, J.; Tillmann, W.; Vogt, C. Biocompatibility of rapidly solidified magnesium alloy RS66 as a temporary biodegradable metal. Acta Biomater. 2013, 9, 8509-8517. [CrossRef] [PubMed]

24. Willbold, E.; Kaya, A.; Kaya, R.; Beckmann, F.; Witte, F. Corrosion of magnesium alloy AZ31 screws is dependent on the implantation site. Mater. Sci. Eng. B 2011, 176, 1835-1840. [CrossRef]

25. Witte, F.; Kaese, V.; Haferkamp, H.; Switzer, E.; Meyer-Lindenberg, A.; Wirth, C.; Windhagen, H. In vivo corrosion of four magnesium alloys and the associated bone response. Biomaterials 2005, 26, 3557-3563. [CrossRef] [PubMed]

26. Witte, F.; Fischer, J.; Nellesen, J.; Crostack, H.-A.; Kaese, V.; Pisch, A.; Beckmann, F.; Windhagen, H. In vitro and in vivo corrosion measurements of magnesium alloys. Biomaterials 2006, 27, 1013-1018. [CrossRef] [PubMed] 
27. Witte, F.; Ulrich, H.; Palm, C.; Willbold, E. Biodegradable magnesium scaffolds: Part II: Peri-implant bone remodeling. J. Biomed. Mater. Res. Part A 2007, 81, 757-765. [CrossRef] [PubMed]

28. Witte, F.; Ulrich, H.; Rudert, M.; Willbold, E. Biodegradable magnesium scaffolds: Part 1: Appropriate inflammatory response. J. Biomed. Mater. Res. Part A 2007, 81, 748-756. [CrossRef] [PubMed]

29. Witte, F.; Fischer, J.; Nellesen, J.; Vogt, C.; Vogt, J.; Donath, T.; Beckmann, F. In vivo corrosion and corrosion protection of magnesium alloy LAE442. Acta Biomater. 2010, 6, 1792-1799. [CrossRef] [PubMed]

30. Xu, L.; Yu, G.; Zhang, E.; Pan, F.; Yang, K. In vivo corrosion behavior of Mg-Mn-Zn alloy for bone implant application. J. Biomed. Mater. Res. Part A Off. J. Soc. Biomater. Jpn. Soc. Biomater. Aust. Soc. Biomater. Korean Soc. Biomater. 2007, 83, 703-711. [CrossRef] [PubMed]

31. Xu, L.; Pan, F.; Yu, G.; Yang, L.; Zhang, E.; Yang, K. In vitro and in vivo evaluation of the surface bioactivity of a calcium phosphate coated magnesium alloy. Biomaterials 2009, 30, 1512-1523. [CrossRef] [PubMed]

32. Yang, J.; Cui, F.; Lee, I.; Zhang, Y.; Yin, Q.; Xia, H.; Yang, S. In vivo biocompatibility and degradation behavior of $\mathrm{Mg}$ alloy coated by calcium phosphate in a rabbit model. J. Biomater. Appl. 2012, 27, 153-164. [CrossRef] [PubMed]

33. Zhang, E.; Xu, L.; Yu, G.; Pan, F.; Yang, K. In vivo evaluation of biodegradable magnesium alloy bone implant in the first 6 months implantation. J. Biomed. Mater. Res. Part A: Off. J. Soc. Biomater. Jpn. Soc. Biomater. Aust. Soc. Biomater. Korean Soc. Biomater. 2009, 90, 882-893. [CrossRef] [PubMed]

34. Zhang, S.; Zhang, X.; Zhao, C.; Li, J.; Song, Y.; Xie, C.; Tao, H.; Zhang, Y.; He, Y.; Jiang, Y. Research on an $\mathrm{Mg}-\mathrm{Zn}$ alloy as a degradable biomaterial. Acta Biomater. 2010, 6, 626-640. [CrossRef] [PubMed]

35. Turvey, T.; Proffit, W.; Phillips, C. Biodegradable fixation for craniomaxillofacial surgery: A 10-year experience involving 761 operations and 745 patients. Int. J. Oral Maxillofac. Surg. 2011, 40, $244-249$. [CrossRef] [PubMed]

36. Meslemani, D.; Kellman, R.M. Recent advances in fixation of the craniomaxillofacial skeleton. Curr. Opin. Otolaryngol. Head Neck Surg. 2012, 20, 304-309. [CrossRef] [PubMed]

37. Suuronen, R.; Pohjonen, T.; Vasenius, J.; Vainionpää, S. Comparison of absorbable self-reinforced multilayer poly-1-lactide and metallic plates for the fixation of mandibular body osteotomies: An experimental study in sheep. J. Oral Maxillofac. Surg. 1992, 50, 255-262. [CrossRef]

38. Bell, R.B.; Kindsfater, C.S. The use of biodegradable plates and screws to stabilize facial fractures. J. Oral Maxillofac. Surg. 2006, 64, 31-39. [CrossRef] [PubMed]

39. Waizy, H.; Weizbauer, A.; Maibaum, M.; Witte, F.; Windhagen, H.; Lucas, A.; Denkena, B.; Meyer-Lindenberg, A.; Thorey, F. Biomechanical characterisation of a degradable magnesium-based (MgCa0.8) screw. J. Mater. Sci. Mater. Med. 2012, 23, 649-655. [CrossRef] [PubMed]

40. Denkena, B.; Podolsky, C.; Lucas, A.; Hassel, T.; Witte, F.; Palm, O. Processing of degradable surgical implants made of magnesium alloys. Biomaterialien 2005, 6, 171.

41. Denkena, B.; Witte, F.; Podolsky, C.; Lucas, A. Degradable Implants Made of Magnesium Alloys. In Proceedings of the 5th Euspen International Conference, Montpellier, France, 8-11 May 2005; pp. 1-4.

42. Witte, F.; Podolsky, C.; Hassel, T.; Lucas, A. Fertigung von magnesium-implantaten. Werkstattstechnik 2004, 94, 692-696.

43. Reichert, J.C.; Hutmacher, D.W. Bone tissue engineering. In Tissue Engineering; Springer: Berlin/Heidelberg, Germany, 2011; pp. 431-456.

44. Mravic, M.; Péault, B.; James, A.W. Current trends in bone tissue engineering. Biomed Res. Int. 2014, 2014, 865270. [CrossRef] [PubMed]

45. Yusop, A.; Bakir, A.; Shaharom, N.; Kadir, M.A.; Hermawan, H. Porous biodegradable metals for hard tissue scaffolds: A review. Int. J. Biomater. 2012, 2012, 641430. [CrossRef] [PubMed]

46. Ryan, G.; Pandit, A.; Apatsidis, D.P. Fabrication methods of porous metals for use in orthopaedic applications. Biomaterials 2006, 27, 2651-2670. [CrossRef] [PubMed]

47. Wei, K.; Gao, M.; Wang, Z.; Zeng, X. Effect of energy input on formability, microstructure and mechanical properties of selective laser melted AZ91D magnesium alloy. Mater. Sci. Eng. A 2014, 611, 212-222. [CrossRef]

48. Wu, S.; Liu, X.; Yeung, K.W.; Liu, C.; Yang, X. Biomimetic porous scaffolds for bone tissue engineering. Mater. Sci. Eng. R: Rep. 2014, 80, 1-36. [CrossRef]

49. Ma, R.; Lai, Y.-X.; Li, L.; Tan, H.-L.; Wang, J.-L.; Li, Y.; Tang, T.-T.; Qin, L. Bacterial inhibition potential of 3D rapid-prototyped magnesium-based porous composite scaffolds-An in vitro efficacy study. Sci. Rep. 2015, 5, 13775. [CrossRef] [PubMed] 
50. Misch, C.E.; Qu, Z.; Bidez, M.W. Mechanical properties of trabecular bone in the human mandible: implications for dental implant treatment planning and surgical placement. J. Oral Maxillofac. Surg. 1999, 57, 700-706. [CrossRef]

51. Yi, W.-J.; Heo, M.-S.; Lee, S.-S.; Choi, S.-C.; Huh, K.-H.; Lee, S.-P. Direct measurement of trabecular bone anisotropy using directional fractal dimension and principal axes of inertia. Oral Surg. Oral Med. Oral Pathol. Oral Radiol. Endodontology 2007, 104, 110-116. [CrossRef] [PubMed]

52. Malawer, M.M.; Chou, L.B. Prosthetic survival and clinical results with use of large-segment replacements in the treatment of high-grade bone sarcomas. JBJS 1995, 77, 1154-1166. [CrossRef]

53. Riede, U.; Lüem, M.; Ilchmann, T.; Eucker, M.; Ochsner, P.E. The ME Müller straight stem prosthesis: 15 year follow-up. Survivorship and clinical results. Arch. Orthop. Trauma Surg. 2007, 127, 587-592. [CrossRef] [PubMed]

54. Tideman, H.; Lee, S. The TL endoprosthesis for mandibular reconstruction-A metallic yet biological approach. Asian J Oral Maxfac Surg 2006, 18, 5.

55. Wong, R.C.; Tideman, H.; Merkx, M.A.; Jansen, J.; Goh, S.M. The modular endoprosthesis for mandibular body replacement. Part 2: Finite element analysis of endoprosthesis reconstruction of the mandible. J. Cranio-Maxillofac. Surg. 2012, 40, e487-e497. [CrossRef] [PubMed]

56. Goh, B.T.; Lee, S.; Tideman, H.; Stoelinga, P.J. Replacement of the condyle and ascending ramus by a modular endoprosthesis in Macaca fascicularis-Part 1: a clinical and radiographic study. J. Oral Maxillofac. Surg. 2009, 67, 1392-1400. [CrossRef] [PubMed]

57. Kujur, M.S.; Manakari, V.; Parande, G.; Tun, K.S.; Mallick, A.; Gupta, M. Enhancement of thermal, mechanical, ignition and damping response of magnesium using nano-ceria particles. Ceram. Int. 2018, 44, 15035-15043. [CrossRef]

58. Gupta, M.; Parande, G.; Manakari, V. An Insight into High Performance Magnesium Alloy/Nano-Metastable-Syntactic Composites. In Proceedings of the 17th Australian International Aerospace Congress: AIAC 2017, Engineers Australia, Royal Aeronautical Society, Melbourne, Australia, 26-28 February 2017; p. 270.

59. Parande, G.; Manakari, V.; Meenashisundaram, G.K.; Gupta, M. Enhancing the tensile and ignition response of monolithic magnesium by reinforcing with silica nanoparticulates. J. Mater. Res. 2017, 32, 2169-2178. [CrossRef]

60. Manakari, V.; Parande, G.; Gupta, M. Effects of hollow fly-ash particles on the properties of magnesium matrix syntactic foams: A review. Mater. Perform. Charact. 2016, 5, 116-131. [CrossRef]

61. Esmaily, M.; Svensson, J.; Fajardo, S.; Birbilis, N.; Frankel, G.; Virtanen, S.; Arrabal, R.; Thomas, S.; Johansson, L. Fundamentals and advances in magnesium alloy corrosion. Prog. Mater. Sci. 2017, 89, 92-193. [CrossRef]

62. Manakari, V.; Parande, G.; Gupta, M. Selective laser melting of magnesium and magnesium alloy powders: A review. Metals 2016, 7, 2. [CrossRef]

63. Manakari, V.; Parande, G.; Doddamani, M.; Gupta, M. Enhancing the ignition, hardness and compressive response of magnesium by reinforcing with hollow glass microballoons. Materials 2017, 10, 997. [CrossRef] [PubMed]

64. Johnston, S.; Shi, Z.; Atrens, A. The influence of $\mathrm{pH}$ on the corrosion rate of high-purity Mg, AZ91 and ZE41 in bicarbonate buffered Hanks' solution. Corros. Sci. 2015, 101, 182-192. [CrossRef]

65. Toda-Caraballo, I.; Galindo-Nava, E.I.; Rivera-Díaz-del-Castillo, P.E. Understanding the factors influencing yield strength on Mg alloys. Acta Mater. 2014, 75, 287-296. [CrossRef]

66. Parande, G.; Manakari, V.; Meenashisundaram, G.K.; Gupta, M. Enhancing the hardness/compression/ damping response of magnesium by reinforcing with biocompatible silica nanoparticulates. Int. J. Mater. Res. 2016, 107, 1091-1099. [CrossRef]

67. Kujur, M.S.; Mallick, A.; Manakari, V.; Parande, G.; Tun, K.S.; Gupta, M. Significantly enhancing the ignition/compression/damping response of monolithic magnesium by addition of $\mathrm{Sm}_{2} \mathrm{O}_{3}$ nanoparticles. Metals 2017, 7, 357. [CrossRef]

68. Parande, G.; Manakari, V.; Kopparthy, S.D.S.; Gupta, M. Utilizing low-cost eggshell particles to enhance the mechanical response of Mg-2.5Zn magnesium alloy matrix. Adv. Eng. Mater. 2018, 20, 1700919. [CrossRef] 
69. Walker, J.; Shadanbaz, S.; Woodfield, T.B.; Staiger, M.P.; Dias, G.J. Magnesium biomaterials for orthopedic application: A review from a biological perspective. J. Biomed. Mater. Res. Part B Appl. Biomater. 2014, 102, 1316-1331. [CrossRef] [PubMed]

70. Witte, F. The history of biodegradable magnesium implants: A review. Acta Biomater. 2010, 6, 1680-1692. [CrossRef] [PubMed]

71. Guan, X.; Xiong, M.; Zeng, F.; Xu, B.; Yang, L.; Guo, H.; Niu, J.; Zhang, J.; Chen, C.; Pei, J. Enhancement of osteogenesis and biodegradation control by brushite coating on $\mathrm{Mg}-\mathrm{Nd}-\mathrm{Zn}-\mathrm{Zr}$ alloy for mandibular bone repair. ACS Appl. Mater. Interfaces 2014, 6, 21525-21533. [CrossRef] [PubMed]

72. Van den Bos, T.; Speijer, D.; Bank, R.; Brömme, D.; Everts, V. Differences in matrix composition between calvaria and long bone in mice suggest differences in biomechanical properties and resorption: Special emphasis on collagen. Bone 2008, 43, 459-468. [CrossRef] [PubMed]

73. Wang, C.; Wang, S.; Yao, Y.; Cui, F. Study on vertical mandibular distraction osteogenesis using magnesium alloy on canine. Prog. Nat. Sci. Mater. Int. 2014, 24, 446-451. [CrossRef]

74. Guo, C.-W.; Yu, Q.; Sun, B.-Z.; Wang, C.-Y.; Yang, J.-X. Evaluation of alveolar bone repair with mineralized collagen block reinforced with Mg-Ca alloy rods. J. Biomater. Tissue Eng. 2018, 8, 1-10. [CrossRef]

75. Lee, J.-H.; Han, H.-S.; Kim, Y.-C.; Lee, J.-Y.; Lee, B.-K. Stability of biodegradable metal (Mg-Ca-Zn alloy) screws compared with absorbable polymer and titanium screws for sagittal split ramus osteotomy of the mandible using the finite element analysis model. J. Cranio-Maxillofac. Surg. 2017, 45, 1639-1646. [CrossRef] [PubMed]

76. Wang, C.-Y.; Kang, C.-Y.; Zhang, S.-N.; Yang, J.-X.; Cheng, G. Study on repairing canine mandibular defect with Mg-Sr alloy. J. Biomater. Tissue Eng. 2018, 8, 11-19. [CrossRef]

77. Ding, W. Opportunities and challenges for the biodegradable magnesium alloys as next-generation biomaterials. Regen. Biomater. 2016, 3, 79-86. [CrossRef] [PubMed]

78. Qureshi, W.; Kannan, S.; Vincent, S.; Eddine, N.; Muhammed, A.; Gupta, M.; Karthikeyan, R.; Badari, V. Influence of Silica Nanospheres on Corrosion Behavior of Magnesium Matrix Syntactic Foam. In Proceedings of the IOP Conference Series: Materials Science and Engineering, Dubai, UAE, 28-29 November 2017; IOP Publishing: Dubai, UAE, 2018; p. 012012.

79. Gupta, M.; Meenashisundaram, G.K. Insight into Designing Biocompatible Magnesium Alloys and Composites: Processing, Mechanical and Corrosion Characteristics; Springer: Singapore, 2015.

80. Erinc, M.; Sillekens, W.; Mannens, R.; Werkhoven, R. Applicability of Existing Magnesium Alloys as Biomedical Implant Materials. In Proceedings of the Magnesium Technology 2009, San Francisco, CA, USA, 15-19 February 2009.

81. Albayrak, O.; El-Atwani, O.; Altintas, S. Hydroxyapatite coating on titanium substrate by electrophoretic deposition method: effects of titanium dioxide inner layer on adhesion strength and hydroxyapatite decomposition. Surf. Coat. Technol. 2008, 202, 2482-2487. [CrossRef]

82. Staiger, M.P.; Pietak, A.M.; Huadmai, J.; Dias, G. Magnesium and its alloys as orthopedic biomaterials: A review. Biomaterials 2006, 27, 1728-1734. [CrossRef] [PubMed]

83. Tang, J.; Wang, J.; Xie, X.; Zhang, P.; Lai, Y.; Li, Y.; Qin, L. Surface coating reduces degradation rate of magnesium alloy developed for orthopaedic applications. J. Orthop. Transl. 2013, 1, 41-48. [CrossRef]

84. Wang, J.; Tang, J.; Zhang, P.; Li, Y.; Wang, J.; Lai, Y.; Qin, L. Surface modification of magnesium alloys developed for bioabsorbable orthopedic implants: A general review. J. Biomed. Mater. Res. Part B: Appl. Biomater. 2012, 100, 1691-1701. [CrossRef] [PubMed]

85. Ong, J.L.; Chan, D.C. Hydroxyapatite and their use as coatings in dental implants: A review. Crit. Rev. ${ }^{\mathrm{TM}}$ Biomed. Eng. 2000, 28, 1-41. [CrossRef]

86. Chai, H.; Guo, L.; Wang, X.; Gao, X.; Liu, K.; Fu, Y.; Guan, J.; Tan, L.; Yang, K. In vitro and in vivo evaluations on osteogenesis and biodegradability of a $\beta$-tricalcium phosphate coated magnesium alloy. J. Biomed. Mater. Res. Part A 2012, 100, 293-304. [CrossRef] [PubMed]

87. Dorozhkin, S.V. Calcium orthophosphate coatings on magnesium and its biodegradable alloys. Acta Biomater. 2014, 10, 2919-2934. [CrossRef] [PubMed]

88. Razavi, M.; Fathi, M.; Savabi, O.; Vashaee, D.; Tayebi, L. In vivo assessments of bioabsorbable AZ91 magnesium implants coated with nanostructured fluoridated hydroxyapatite by MAO/EPD technique for biomedical applications. Mater. Sci. Eng. C 2015, 48, 21-27. [CrossRef] [PubMed] 
89. Tang, H.; Yu, D.; Luo, Y.; Wang, F. Preparation and characterization of HA microflowers coating on AZ31 magnesium alloy by micro-arc oxidation and a solution treatment. Appl. Surf. Sci. 2013, 264, 816-822. [CrossRef]

90. Sun, J.E.; Wang, J.; Jiang, H.; Chen, M.; Bi, Y.; Liu, D. In vivo comparative property study of the bioactivity of coated Mg-3Zn-0.8 Zr alloy. Mater. Sci. Eng. C 2013, 33, 3263-3272. [CrossRef] [PubMed]

91. Zheng, Y.; Gu, X.; Witte, F. Biodegradable metals. Mater. Sci. Eng. R: Rep. 2014, 77, 1-34. [CrossRef]

92. Wu, G.; Ibrahim, J.M.; Chu, P.K. Surface design of biodegradable magnesium alloys-A review. Surf. Coat. Technol. 2013, 233, 2-12. [CrossRef]

93. Xu, L.; Yamamoto, A. Characteristics and cytocompatibility of biodegradable polymer film on magnesium by spin coating. Colloids Surf. B: Biointerfaces 2012, 93, 67-74. [CrossRef] [PubMed]

94. Kaplan, F.; Hayes, W.; Keaveny, T.; Boskey, A.; Einhorn, T.; Iannotti, J. Form and function of bone. Orthop. Basic Sci. 1994, 127-185.

95. Webster, T.J.; Ergun, C.; Doremus, R.H.; Siegel, R.W.; Bizios, R. Specific proteins mediate enhanced osteoblast adhesion on nanophase ceramics. J. Biomed. Mater. Res. Off. J. Soc. Biomater. Jpn. Soc. Biomater. Aust. Soc. Biomater. Korean Soc. Biomater. 2000, 51, 475-483. [CrossRef]

96. Webster, T.J.; Siegel, R.W.; Bizios, R. Nanoceramic surface roughness enhances osteoblast and osteoclast functions for improved orthopaedic/dental implant efficacy. Scr. Mater. 2001, 44, 1639-1642. [CrossRef]

97. Liu, H.; Slamovich, E.B.; Webster, T.J. Increased osteoblast functions on nanophase titania dispersed in poly-lactic-co-glycolic acid composites. Nanotechnology 2005, 16, S601. [CrossRef] [PubMed]

98. Wei, G.; Ma, P.X. Structure and properties of nano-hydroxyapatite/polymer composite scaffolds for bone tissue engineering. Biomaterials 2004, 25, 4749-4757. [CrossRef] [PubMed]

99. Webster, T.J.; Siegel, R.W.; Bizios, R. Osteoblast adhesion on nanophase ceramics. Biomaterials 1999, 20, 1221-1227. [CrossRef]

100. Liu, H.; Webster, T.J. Bioinspired Nanocomposites for Orthopedic Applications. In Nanotechnology for the Regeneration of Hard and Soft Tissues; World Scientific: Cranston, RI, USA, 2007; pp. 1-51.

101. Hickey, D.J.; Ercan, B.; Chung, S.; Webster, T.J.; Sun, L.; Geilich, B. MgO Nanocomposites as New Antibacterial Materials for Orthopedic Tissue Engineering Applications. In Proceedings of the Bioengineering Conference (NEBEC), 2014 40th Annual Northeast, IEEE, 2014, Boston, MA, USA, 25-27 April 2014; pp. 1-2.

102. Kumar, A.; Meenashisundaram, G.K.; Manakari, V.; Parande, G.; Gupta, M. Lanthanum effect on improving CTE, damping, hardness and tensile response of Mg-3Al alloy. J. Alloy. Compd. 2017, 695, 3612-3620. [CrossRef]

103. Meenashisundaram, G.K.; Ong, T.H.D.; Parande, G.; Manakari, V.; Xiang, S.; Gupta, M. Using lanthanum to enhance the overall ignition, hardness, tensile and compressive strengths of Mg-0.5 Zr alloy. J. Rare Earths 2017, 35, 723-732. [CrossRef]

104. Parande, G.; Manakari, V.; Wakeel, S.; Kujur, M.; Gupta, M. Enhancing Mechanical Response of Monolithic Magnesium Using Nano-NiTi (Nitinol) Particles. Metals 2018, 8, 1014. [CrossRef]

105. Wakeel, S.; Manakari, V.; Parande, G.; Kujur, M.S.; Gupta, M. Synthesis and mechanical response of NiTi SMA nanoparticle reinforced $\mathrm{Mg}$ composites synthesized through microwave sintering process. Mater. Today: Proc. 2018, 5, 28203-28210. [CrossRef]

106. Parande, G.; Manakari, V.; Gupta, H.; Gupta, M. Magnesium- $\beta$-tricalcium phosphate composites as a potential orthopedic implant: A mechanical/damping/immersion perspective. Metals 2018, 8, 343. [CrossRef]

107. Meenashisundaram, G.; Gupta, M. Emerging environment friendly, magnesium-based composite technology for present and future generations. JOM 2016, 68, 1890-1901. [CrossRef]

108. Ong, T.H.D.; Yu, N.; Meenashisundaram, G.K.; Schaller, B.; Gupta, M. Insight into cytotoxicity of Mg nanocomposites using MTT assay technique. Mater. Sci. Eng. C 2017, 78, 647-652. [CrossRef] [PubMed]

109. Khalajabadi, S.Z.; Abu, A.H.; Ahmad, N.; Kadir, M.; Ismail, A.; Nasiri, R.; Haider, W.; Redzuan, N. Biodegradable $\mathrm{Mg} / \mathrm{HA} / \mathrm{TiO}_{2}$ nanocomposites coated with $\mathrm{MgO}$ and $\mathrm{Si} / \mathrm{MgO}$ for orthopedic applications: A study on the corrosion, surface characterization, and biocompatibility. Coatings 2017, 7, 154. [CrossRef]

110. Haghshenas, M. Mechanical characteristics of biodegradable magnesium matrix composites: A review. J. Magnes. Alloy. 2017, 5, 189-201. [CrossRef] 
111. Prakash, C.; Singh, S.; Gupta, M.; Mia, M.; Królczyk, G.; Khanna, N. Synthesis, characterization, corrosion resistance and in-vitro bioactivity behavior of biodegradable $\mathrm{Mg}-\mathrm{Zn}-\mathrm{Mn}-(\mathrm{Si}-\mathrm{HA})$ composite for orthopaedic applications. Materials 2018, 11, 1602. [CrossRef] [PubMed]

112. Huang, L. Molecular hydrogen: A therapeutic antioxidant and beyond. Med Gas Res. 2016, 6, 219. [CrossRef] [PubMed]

113. Glocker, D.; Ranade, S. Medical Coatings and Deposition Technologies; John Wiley \& Sons: Beverly, MA, USA, 2016.

114. Song, G.L.; Atrens, A. Corrosion mechanisms of magnesium alloys. Adv. Eng. Mater. 1999, 1, 11-33. [CrossRef]

115. Gu, X.; Zhou, W.; Zheng, Y.; Cheng, Y.; Wei, S.; Zhong, S.; Xi, T.; Chen, L. Corrosion fatigue behaviors of two biomedical Mg alloys-AZ91D and WE43-in simulated body fluid. Acta Biomater. 2010, 6, 4605-4613. [CrossRef] [PubMed]

(C) 2019 by the authors. Licensee MDPI, Basel, Switzerland. This article is an open access article distributed under the terms and conditions of the Creative Commons Attribution (CC BY) license (http://creativecommons.org/licenses/by/4.0/). 